Turkish Online Journal of Qualitative Inquiry (TOJQI)

Volume 11, Issue 2, April 2020: 161-192

DOI: $10.17569 /$ tojqi.618950

Research Article

\title{
Preservice Science Teachers' Views about Scientific Inquiry: The Case of Turkey and Taiwan ${ }^{1,2}$
}

\author{
Hatice Baykara ${ }^{3}$, Zeha Yakar ${ }^{4}$
}

\begin{abstract}
In recent years, the importance of examining the opinions of preservice science teachers who will educate future science literate individuals towards scientific research has been frequently mentioned. In this research, in order to contribute to the field, 88 preservice science teachers in Turkey and 80 preservice science teachers in Taiwan participated in the study. The data was collected via Views about Scientific Inquiry - VASI Questionnaires. Also, semi-structured interviews with volunteered preservice science teachers. Results showed that there is a significant difference on behalf of preservice science teachers in Taiwan in terms of "the way that the scientific inquiries are done", "the place of experiment and observation in scientific inquiries" as for the first dimension, and "there is no single set or sequence of steps followed in all inquiries" as for the second dimension. Besides, the preservice science teachers from both countries stated their views in "scientific" level on the dimension of "The result of an inquiry should be in accordance with the collected data". Moreover, it was revealed that preservice science teachers in Turkey have difficulty in defining that scientific research always starts with a question; and preservice science teachers in Taiwan have difficulty in defining the scientific data and scientific evidence. Considering all the findings, preservice science teachers' views of scientific inquiry in Taiwan are better than them in Turkey.
\end{abstract}

Keywords: Scientific literacy, views about scientific inquiry, pre-service science teachers, science teacher education program

\footnotetext{
${ }^{1}$ This article is derived from Hatice Baykara's Doctoral Dissertation entitled "Preservice teachers' views of scientific inquiry and world views: Turkey and Taiwan case",conducted under the supervision of Zeha Yakar. ${ }^{2}$ The ethical committee permission is not required in this study since the data were gathered before 2020 and within the scope of a master's/doctoral thesis.

${ }^{3}$ Dr., Pamukkale University, Faculty of Eduction, Department of Mathematics and Science Education, gulerhatice@gmail.com, https://orcid.org/0000-0002-5219-9782

${ }_{4}^{4}$ Doç.Dr., Pamukkale University, Faculty of Education, Department of Mathematics and Science Education, zyakar@pau.edu.tr, https://orcid.org/0000-0003-4221-2821
}

Received: 11.09.2019, Accepted: 29.04.2020 


\title{
Fen Öğretmen Adaylarının Bilimsel Araştırmaya Yönelik Görüşleri: Türkiye ve Tayvan Örneği
}

\begin{abstract}
$\ddot{O} \mathbf{z}$
Son yıllarda, geleceğin bilim okuryazarı bireylerini yetiştirecek olan öğretmen adaylarının bilimsel araştırmaya yönelik sahip oldukları görüşlerin incelenmesinin öneminden sıklıkla bahsedilmektedir. $\mathrm{Bu}$ doğrultuda alana katkı sağlamak amacıyla bu araştırmada, Türkiye ve Tayvan'daki fen öğretmen adaylarının bilimsel araştırmaya yönelik görüşleri incelenmiştir. Bu amaçla Türkiye'den 88 öğretmen adayı ve Tayvan'dan 80 öğretmen adayından bilimsel araştırmaya yönelik veriler toplanmıştır. Fen öğretmen adaylarının bilimsel araştırmaya yönelik görüşlerinin araştırılması için Lederman ve Lederman, Lederman, Bartos, Bartel, Meyer ve Schwartz (2014) tarafindan geliştirilen Views About Scientific Inquiry Qustionnaire- VASI kullanılmıştır. Tarama modelinde olan bu araştırmada nitel ve nicel veri analizi yapılmıştır. Ayrıca ölçekte yer alan açık uçlu sorular sorularak, seçilen öğretmen adaylarıyla görüşmeler gerçekleştirilmiştir. Çalışmadan elde edilen bulgular doğrultusunda fen öğretmen adaylarının, bilimsel araştırmaların yapılışına ve deney-gözlemin bilimsel araştırmalardaki yerine ilişkin olan bilimsel araştırmanın birinci boyutuna ve bilimsel araştırmaların belli bir yöntemi ve basamağının olmadığına ilişkin olan ikinci boyutuna yönelik verdikleri cevaplarda ülke değişkenine göre Tayvan'daki fen öğretmen adayları lehine anlamlı bir farklılığın olduğu ortaya konmuştur. Ayrıca her iki ülkedeki fen öğretmen adaylarının bilimsel araştırmaya yönelik görüşlerinin "Çalışmanın sonucu, toplanan verilerle tutarlı olmalıdır" boyutunda "bilimsel" görüş düzeyinde toplandığ1 görülmüştür. Bunun yanında Türkiye'deki öğretmen adaylarının "Bilimsel araştırmalar her zaman bir problemle başlar" boyutunda; Tayvan'daki öğretmen adaylarının ise "veriler, kanıtlarla aynı değildir" boyutlarında çoğunlukla "yetersiz" görüş düzeyinde görüsse sahip oldukları belirlenmiştir. Sonuç olarak bilimsel araştırma düzeyleri göz önünde bulundurulduğunda Tayvan'daki öğretmen adaylarının Türkiye'deki öğretmen adaylarına göre daha iyi oldukları söylenebilir.
\end{abstract}

Anahtar Kelimeler: Bilimsel okuryazarlık, bilimsel araştırmaya yönelik görüş, fen ögrretmen adaylarl, fen ögretmen yetiştirme programı 


\section{Introduction}

The most important effects of the education system on society are that science affects a society positively, scientific thinking is spread among the masses of the public and science becomes a part of common thinking. Giving scientific quality to the cultural structure should be among the primary objectives of education at all levels, starting from primary school level. Students trained by the education system prepared for this purpose will be scientific literate individuals who can combine science with art and moral values, use scientific research skills, and find effective solutions to the problems they face today and in the future (MEB, 2005, 2018; Lederman ve Lederman, 2012). Scientific literacy in American National Science Education Standards (NSTA, 2003) is defined as knowing and applying scientific concepts and processes for making personal decisions, participating in social and cultural events and economic productivity (NRC, 1996). Briefly, scientific literacy requires being familiar with scientific issues, understanding scientific initiative, relationships between science and society (AAAS, 1993). For this reason, it is of great importance to teach students the nature of science and the nature of scientific inquiry, which are the most basic components of science literacy (Solomon, 1991; Reif \& Larkin, 1991; Driver, Leach, Millar \& Scott, 1996). Scientific inquiry is an important factor for students to think like scientists, develop positive opinions about science, and develop critical thinking skills in structuring knowledge and increase students' academic success (Anderson, 2002; Schneider, Krajcik, Marx \& Soloway, 2002).

Today, the information that societies produce and share increases with such a speed that the effect of information on the progress of societies is also revealed. In the information age we are in, one of the most important needs is not to reach information, but to be aware of where and how to get the right information. In order to create this awareness and increase the number of scientific literate people of the society, it is very important that the education system of that society aims to provide its students with the skills to reach information rather than transferring the existing information. However, no matter how well the goals are determined in education and training, no matter how functional the course subjects are, it is not possible to get the expected result unless there are teachers with those goals and insights. For this reason, the most important element of an education system is the teacher. Teachers responsible for educating and directing students for educational purposes are expected to develop their understanding of 
scientific issues, develop their skills for the nature and use of scientific processes, and guide their students in practicing in their life what they have learned in science classes (Kilpatrick, Swafford \& Findell, 2001; Hill, Rowan, \& Ball, 2005). However, current research has also shown that science teachers reflect their understanding of science, their views on science and their attitudes towards science into classroom practices (Akerson, Abd-El-Khalick \& Lederman, 2000; Morrison, Raab \& Ingram, 2009). American National Science Education Standards [NSES] (NRC, 1996) have established standards for the characteristics that teachers should have and listed these standards as follows: "All science teachers will understand the nature of scientific research, state the importance and importance of scientific research in science, have enough scientific knowledge to use it." (p.59). However, it is also stated in the studies conducted that the opinions of teachers and students about scientific research are not sufficient (Abd-El-Khalick, Lederman, 2000; Lederman, 2009; Lederman, Lederman, Bartos, Bartles, Meyer, and Schwartz, 2013; Schwartz, Lederman and Lederman, 2008). In the light of these studies, the most important research to be done to improve the education system is to examine teacher training programs. In other words, the education of teachers who will work in the education system in teacher training programs is important in terms of the quality of education. Accordingly, teacher training programs should be shaped according to the changing conditions of today, the competencies of teacher training programs should be reviewed, and the policies followed for the current situation and the desired targets should be constantly evaluated through field research. Therefore, it is of utmost importance to determine the pre-service teachers' understanding of scientific inquiry in order to train teachers who can make scientific inquiry applications and offer their students opportunities in this direction (Ma, 2011; Wang, Lv, Jou, and Zhang, 2016).

Individuals who are aware of the interaction between science and society and can conduct a scientific research, in order to raise science literate individuals, many countries organize their education programs for this purpose and take part in international educational performance comparison practices to evaluate their results. Among these applications, "Trends in International Mathematics and Science Study (TIMSS)" and "Program for International Student Assessment (PISA)" are the most commonly used. These international comparison exams play an important role in assessing changes in the education system and identifying deficiencies. In other words, in the light of the data obtained from such studies, issues such as strengths and weaknesses of the current education system, education policies, curriculum, teaching methods 
and techniques, and competencies of teachers are reviewed (Keser, 2005; Brown \& Brown, 2007).

One of the most important elements of the education system is teachers and teachers are shaped by the current education system (Kilpatrick, Swafford \& Findell, 2001; Hill, Rowan \& Ball, 2005). Therefore, studying teacher training should be one of the first steps to be taken to improve the education system in general. At the ranking of PISA and TIMSS exams, while Taiwan occupies on top position; unfortunately, Turkey is situated below the average. The literature review shows that they have a similar system of science education in Taiwan and Turkey. However, it is also seen that they have different science teacher training and selection policies (MEB, 2016).

Constructivism is the basis of science teacher training programs in both countries, and programs are based on practice-based education. The programs included the nature of science courses in order to develop pre-service teachers' understanding of science, elements of science and scientific inquiry. In addition, preservice teachers in both countries take scientific research and laboratory courses and perform various applications. Educational sciences courses in both countries' science teacher training programs are similar (MOE-Taiwan, 2001\& HEI, 2007). However, there are also some differences between the two countries in terms of understanding of raising science teachers. The first of these, science teacher training programs are four-year programs in Turkey. Preservice science teachers must complete these programs. Those who succeed at the end of the process can graduate. Prospective teachers who graduate take the central exam and those who enter a certain percentage are appointed as teachers. This situation differs in science teacher training institutions in Taiwan. In order to become a science teacher in Taiwan, preservice science teachers must complete the teacher education certificate programs of the college or universities. Individuals who have graduated from different undergraduate programs or are still studying can also continue these programs. Preservice science teachers who graduated from this certificate program, enters a central exam similar to that of Turkey. Then they have to pass the local exam of the region they want to work as a teacher. Although Turkey and Taiwan have different science teacher training policies, the science teaching programs of these two countries aim to raise individuals who understand the nature of scientific inquiry, which is one of the most fundamental components of scientific literacy. Scientific research, which has been researched for a long time in science education, includes scientific process skills used in the structuring of scientific knowledge, and field knowledge, creativity 
and critical thinking skills (Lederman, 2009; Lederman, Lederman, Lederman \& Antink, 2013). While many resources available in this field (AAAS, 1993; NRC, 2011) focus on the importance of these skills to conduct research; in the American National Science Education Standards (National Science Education Standarts- NSES), the difference between the skills required to conduct research and the basic understanding of the character of scientific research has been highlighted. For this reason, today, the focus of science education has been the applications that will bring the skills and understanding towards doing scientific research.

The nature of scientific inquiry includes processes involving the work of scientists, the processes of creating and accepting scientific knowledge (Schwartz, Lederman \& Lederman, 2008; Lederman, Lederman, Bartos, Bartles, Meyer \& Schwartz, 2014). Eight different dimensions have been defined for understanding of scientific research, which is beyond the basic research skills (NRC, 2000, 2011). These dimensions and their explanations are as follows (Lederman et al., 2014);

1. Scientific investigations all begin with a question, but do not necessarily test a hypothesis: In scientific research questions may arise in various ways, sometimes from curiosity and sometimes from a theory-oriented prediction. Scientific inquiry begins with questions, but does not necessarily test a hypothesis.

2. There is no single set and sequence of steps followed in all investigations (i.e., there is no single scientific method): It has also been emphasized in the standards that students should gain awareness that scientists do not follow a single scientific method to conduct their research and produce valid knowledge (NRC, 2011).

3. Inquiry procedures are guided by the question asked: Scientific research mainly consists of the questions asked by the scientist, what they already know about the world and their answers. For this reason, scientists can follow different methods and processes for the same questions. Students need to understand that the research questions determine the approaches to be followed.

4. All scientists performing the same procedures may not get the same results: Students should realize that scientific data alone does not mean anything, scientists interpret scientific data and conclude (Osborne, Collins, Ratcliffe, Miller \& Duschl, 2003). 
5. Inquiry procedures can influence the results: Determining and organizing variables, data collection methods, measuring and analyzing variables affect the results obtained by the researcher. Students need to understand that there is a logical connection between the research method, the data collection method and the conclusion reached.

6. Research conclusions must be consistent with the data collected: Each research result will be supported by evidence from the data collected. Students understand that the strongness of scientists' claims depends on supporting these claims with evidence.

7. Scientific data are not the same as scientific evidence: In scientific research, data are observations collected by the scientist during the research and these observations can take various forms (eg numbers, descriptions, photographs, sound, physical examples, etc.). Evidence is the product of the data analysis process and subsequent comments. In order for students to interpret the data, they must first understand the difference between data and evidence.

\section{Explanations are developed from a combination of collected data and what is already known:}

To statements made by scientists; the data they collect for their research, the results they obtain from these data and the information that has been revealed in previous research and accepted as scientific information are guided. In addition, students should understand that scientists have to define the difference of well-supported results from accepted scientific knowledge or must define the superiority of well-explained phenomena over previous theories (NRC, 2011).

Teachers shaped by the current education system are among the most important factors affecting student success. Therefore, examining teacher training should be one of the first steps to be taken to improve the education system in general. Thus, it is believed that investigation of preservice science teachers' views on scientific inquiry, who have continued science teacher education program in Turkey and Taiwan, and making the comparison between the two countries' views on scientific inquiry will bring a different perspective to teacher training programs in our country. For this purpose, in this study, both in Turkey submissions on the scientific research of science teachers in Taiwan were investigated. 


\section{Method}

The study is a descriptive study in order to determine the pre-service science teachers' opinions about scientific inquiry and survey method, which is one of the descriptive research methods, was used. Survey are research approaches aiming to describe a situation that exists in the past or still as it exists (Büyüköztürk, Çakmak, Akgün, Karadeniz \& Demirel, 2014). The simple descriptive survey approach is one-shot survey for the purpose of describing the characteristics of a sample at one point in time apart (Mertens, 1998).

In this study, 88 preservice science teachers, who continued to the senior class of Science Education department of one university in Turkey; and, 80 preservice science teachers, who continued to the senior class of the National Taiwan Normal University in Taiwan, was participated. In addition, after the application scale, semi-structured interviews were conducted with 10 preservice science teachers from Turkey, and 8 preservice science teachers from Taiwan and the questions in the instrument were asked in the interviews.

\section{Instrument}

In this research, "Views on Scientific Inquiry Questionnaire" consisting of seven open-ended questions, which is a qualitative measurement tool, was used to determine the views of preservice science teachers about scientific inquiry. It was developed by Lederman, Lederman, Bartos, Bartel, Meyer and Schwartz in 2014 with the aim of determining views on scientific inquiry. The translation of VASI into Turkish was made by the researcher and the translation into Chinese was made by experts in the field. In order to ensure the language validity of the instrument, it was converted back to English by academicians who are experts in language fields, and it was used in the study after the necessary corrections were made and pilot application was made. The items of VASI have been prepared to determine eight aspects for scientific research. These aspects are; (1) Scientific investigations all begin with a question, but do not necessarily test a hypothesis. (2) There is no single set and sequence of steps followed in all investigations (i.e., there is no single scientific method). (3) Inquiry procedures are guided by the question asked. (4) All scientists performing the same procedures may not get the same results. (5) Inquiry procedures can influence the results. (6) Research conclusions must be consistent with the data collected. (7) Scientific data are not the same as scientific evidence. (8) Explanations are developed from a combination of collected data and what is already known. 


\section{Data Analysis}

The data obtained in the study were analyzed using content analysis, which is one of the qualitative data analysis methods. In order to examine the responses of the participants to the forms, the rubric developed by Lederman (2014) was used, the pre-service teachers' answers were evaluated, and their views on scientific inquiry were classified as informed, mixed and naive. If preservice science teachers could justify their answers regarding the questions correctly, they were categorized as an "informed" view. Preservice science teachers provided sufficient explanation, but if the reasons for their answers are not clear or incomplete, they are categorized as a "mixed" view. If preservice science teachers did not provide sufficient opinions or their explanations were wrong, their opinions were categorized as "naive" view; and, if the preservice science teachers gave irrelevant or incomprehensible answers to the question, his answers were categorized as "not clear" view. Also, using rubrics, qualitative data collected by VASI was converted into quantitative data. Statistical Package for the Social Sciences-21 (SPSS-21) program was used to analyze the quantitative data obtained. In this study, the ChiSquare Test (Crosstabs) was applied to determine the possible differences between the preservice teachers' answers to the VASI. Because of the fact that this nonparametric statistical analysis method is used to determine whether there are significant differences for events or objects, in this study, it was used to determine the difference between the views on the scientific inquiry of preservice science teachers in Taiwan and Turkey. In addition, frequency and percentage analyzes of the data were performed and interpretations were made by looking at these distributions.

\section{Findings}

In this study, the answers given by preservice science teachers in Turkey and Taiwan who participated in the research were analyzed under the eight aspects of the scientific inquiry and classified as informed, mixed and naive. The views of Turkish and Taiwanese preservice science teachers about the scientific inquiry aspects for these categories are presented in Figure 1 and Figure 2 respectively. 


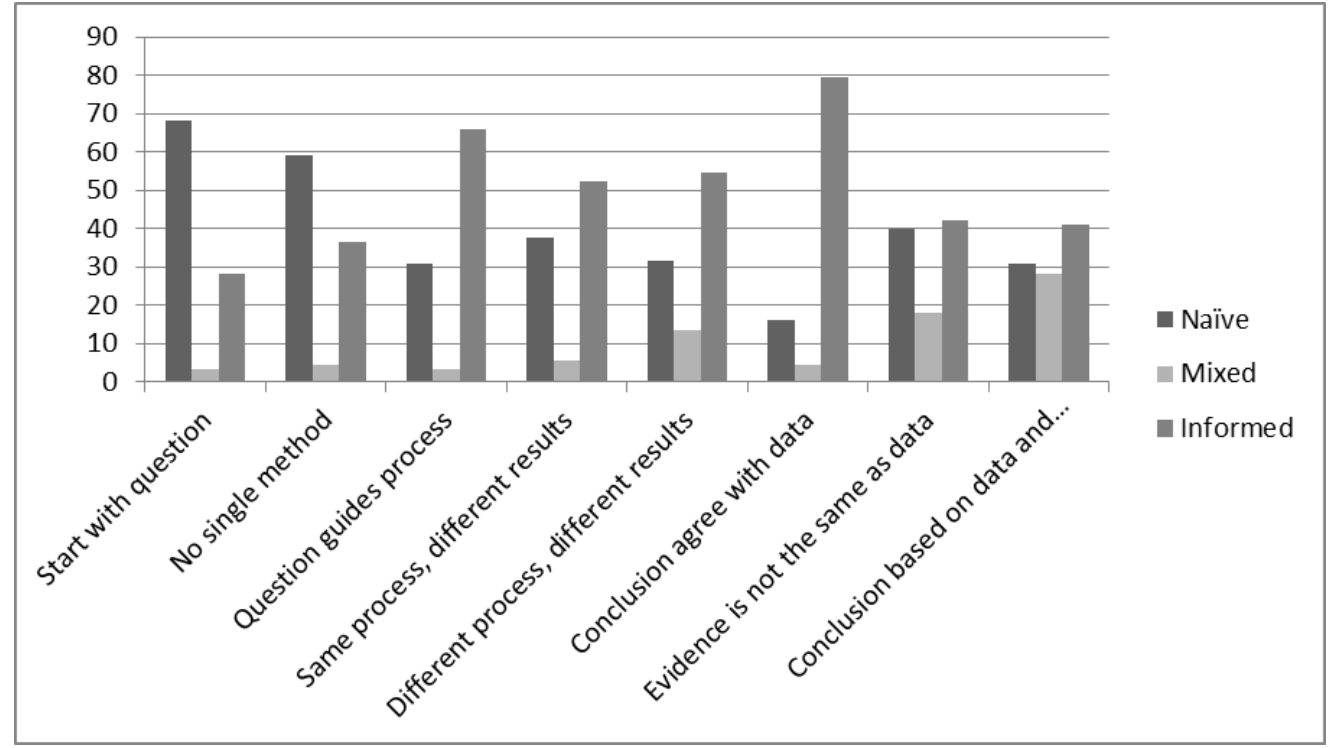

Figure 1. Views on Scientific Inquiry of Preservice Science Teachers in Turkey $(\mathrm{n}=88)$

Considering the graph in Figure 1, the preservice science teachers in Turkey have "informed" view in the four dimensions of scientific research more than naive view.

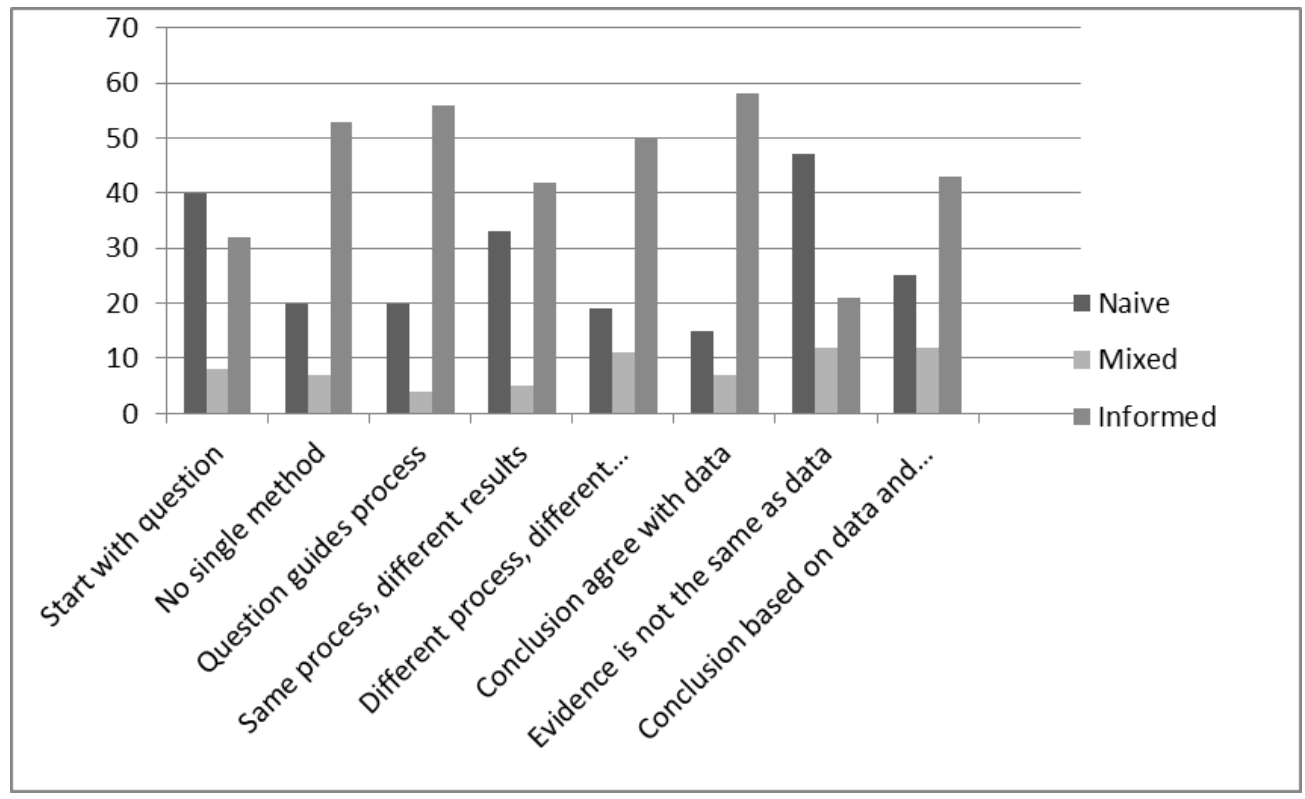

Figure 2. Views on Scientific Inquiry of Preservice Science Teachers in Taiwan $(\mathrm{n}=80)$ 
To consider the graph in Figure 2, the preservice science teachers in Taiwan have "informed" view in the six dimensions of scientific research more than naive view.

\section{Aspect: Scientific investigations all begin with a question, but do not necessarily test a hypothesis}

In Turkey and in Taiwan, some examples of preservice science teachers' responses to the first aspect of scientific inquiry are presented in Table 1.

Table 1.

Examples of Preservice Science Teachers' Responses Representing their Informed, Mixed and Naive Views on the First Aspect of Scientific Inquiry

\begin{tabular}{|c|c|c|c|}
\hline $\begin{array}{l}\text { 1. Aspect of Scientific } \\
\text { Inquiry }\end{array}$ & Informed & Mixed & Naive \\
\hline \multirow[t]{2}{*}{$\begin{array}{l}\text { Scientific } \\
\text { investigations all } \\
\text { begin with a question, } \\
\text { but do not necessarily } \\
\text { test a } \\
\text { hypothesis }\end{array}$} & $\begin{array}{l}\text { It is scientific. This person } \\
\text { may have started with the } \\
\text { question. Why are the } \\
\text { beaks of these birds } \\
\text { different? It started with a } \\
\text { question and continued } \\
\text { with research on it, made } \\
\text { examinations, observed, } \\
\text { and made classification. So } \\
\text { it is scientific. } \\
\text { (PSTTURKEY) }\end{array}$ & $\begin{array}{l}\text { An idea that may not start } \\
\text { with scientific questions. } \\
\text { But to get absolutely } \\
\text { reliable information, that } \\
\text { person puts his curiosity } \\
\text { and question into a } \\
\text { scientific way and starts } \\
\text { his research. In fact, the } \\
\text { research begins with a } \\
\text { scientific question, with } \\
\text { curiosity. (PSTTURKE5) }\end{array}$ & $\begin{array}{l}\text { Scientific research } \\
\text { sometimes begins with } \\
\text { curiosity, not always } \\
\text { with scientific questions. } \\
\text { (PSTTURKEY66) }\end{array}$ \\
\hline & $\begin{array}{l}\text { Scientific inquiry includes } \\
\text { observation, revealing the } \\
\text { problem, presenting and } \\
\text { proving the hypothesis. If } \\
\text { the data is handled } \\
\text { carefully and } \\
\text { systematically when it is } \\
\text { collected and concluded, } \\
\text { the research that this } \\
\text { person has done is } \\
\text { scientific. (PST TAIWAN 9) }\end{array}$ & $\begin{array}{l}\text { Yes, but we need to } \\
\text { define scientific } \\
\text { questions, I think we can } \\
\text { hardly define things like } \\
\text { religion and emotion, for } \\
\text { example. (PST TAIWAN 33) }\end{array}$ & 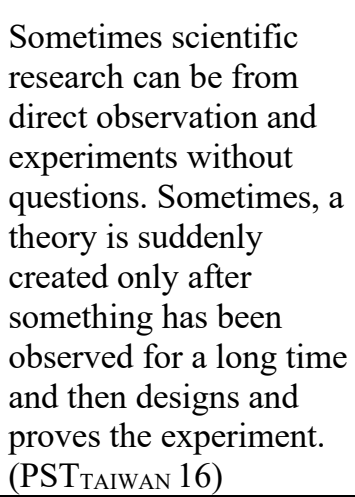 \\
\hline
\end{tabular}

*PST - Preservice Science Teacher

In this aspect of the VASI, the $\mathrm{a}$ and $\mathrm{b}$ part of the first question and the second question targets understanding that scientific inquiry always starts with a problem, that problems that inspire research actually arise from observations and that this is a part of science. The results obtained for this aspect, only $28.4 \%$ of preservice science teachers in Turkey and $40 \%$ of preservice science teachers in Taiwan have "informed" view. When the answers given to the questions in this aspect are examined in detail, in the case of the part a of the first question, opinions of 
whether the birdwatching research given in the question is scientific or not were taken. When the results were examined, it was determined that approximately half of the preservice science teachers in both countries did not have sufficient views about this aspect and that they could not accept the research mentioned in the first question of VASI scientifically, because they stated that only observation was made. In addition, $46.6 \%$ of teachers in Turkey, while $37.5 \%$ of teachers in Taiwan stated that scientific research always starts with a problem, and it is determined that they have "informed" view on this subject.

Also, when the answers to the questions of the first aspects are examined in detail; When the answers given by the Turkish preservice science teachers to the part a of the first question (1a) of the first aspect "Would you scientifically accept the examination of this person?", it was determined that only $19.3 \%$ of their answers were at the level of "informed" view. In addition, $32.5 \%$ of Taiwanese preservice science teachers were found to be at the "informed" view. It has been determined that pre-service teachers at this level are able to provide sufficient answers regarding how scientific research should be together with their reasons, and they use definitions such as "observation were made for research" and "systematic data collection were made". In another question of this dimension, the opinions of the preservice teachers on whether the examination of the bird watcher should be accepted as an experiment or not were received. The findings stated that $76.1 \%$ of preservice science teachers in Turkey and $42.5 \%$ of preservice science teachers in Taiwan was found to have a "naive" view. It was determined that these preservice science teachers could not determine the difference between experiment and observation, and they experienced a confusion about this issue. Moreover, quite a few of the teachers in Turkey, while close to half of the teachers in Taiwan has "informed" view. It was determined that these pre-service teachers could explain the reason for this research sample that it was not an experiment, and could distinguish between experiment and observation. When the findings for the other question of this aspect, for scientific research always start with a problem, in Turkey (50\%) and in Taiwan (61.2\%), most of the preservice science teachers have "naive" view unfortunately. It was found that these preservice science teachers often stated that scientific research could always start with curiosity or by chance, not with questions.

\section{Aspect: There is no single set and sequence of steps followed in all investigations}

In Turkey and in Taiwan, some examples of preservice science teachers' responses to the second aspect of scientific inquiry are presented in Table 2. 
Table 2.

Examples of Preservice Science Teachers' Responses Representing their Informed, Mixed and Naive Views on the Second Aspect of Scientific Inquiry

\begin{tabular}{|c|c|c|c|}
\hline $\begin{array}{l}\text { 2. Aspect of Scientific } \\
\text { Inquiry }\end{array}$ & Informed & Mixed & Naive \\
\hline \multirow[t]{2}{*}{$\begin{array}{l}\text { There is no single set } \\
\text { and sequence of steps } \\
\text { followed in all } \\
\text { investigations }\end{array}$} & $\begin{array}{l}\text { Scientific research can have } \\
\text { more than one method. If } \\
\text { we go through the same } \\
\text { research, the observation } \\
\text { method was used in this } \\
\text { study. Instead, it can also } \\
\text { use the test method by } \\
\text { intervening. There are two } \\
\text { different methods here, both } \\
\text { scientific. (PST TURKEY 55) }\end{array}$ & $\begin{array}{l}\text { It can be done in many } \\
\text { ways, for example, a } \\
\text { researcher can prove the } \\
\text { boiling point of water } \\
\text { with one experiment, } \\
\text { while another researcher } \\
\text { can prove it with another } \\
\text { experiment. (PSTTURKEY } \\
\text { 5) }\end{array}$ & $\begin{array}{l}\text { All scientists follow the } \\
\text { same path. Identifying the } \\
\text { problem, setting up } \\
\text { hypotheses, designing the } \\
\text { experiment, determining } \\
\text { the variables, etc. } \\
\text { (PSTTURKEY 6). }\end{array}$ \\
\hline & $\begin{array}{l}\text { There are different methods. } \\
\text { For example, the first one is } \\
\text { the experiment. Hypotheses } \\
\text { simply follow the } \\
\text { experimental processes and } \\
\text { prove their hypothesis. It } \\
\text { creates hypothesis with } \\
\text { deductive method, tests it } \\
\text { by experiment and supports } \\
\text { its hypothesis. Another } \\
\text { method is survey. By } \\
\text { collecting many data and } \\
\text { classifying (books, } \\
\text { bibliography etc.), analysis } \\
\text { is made and the literature is } \\
\text { collected. Unlike the } \\
\text { experiment, after editing the } \\
\text { data, there is evidence to fit } \\
\text { the hypothesis. The two } \\
\text { methods are different, but } \\
\text { the purpose of the two is to } \\
\text { link the cause and effect in } \\
\text { each study. Both can be } \\
\text { considered scientific } \\
\text { method. (PST }\end{array}$ & $\begin{array}{l}\text { Yes. There are various } \\
\text { methods for testing } \\
\text { surface tension, for } \\
\text { example. You try it with } \\
\text { experiment or.. } \\
\text { (PSTTAIWAN76) }\end{array}$ & 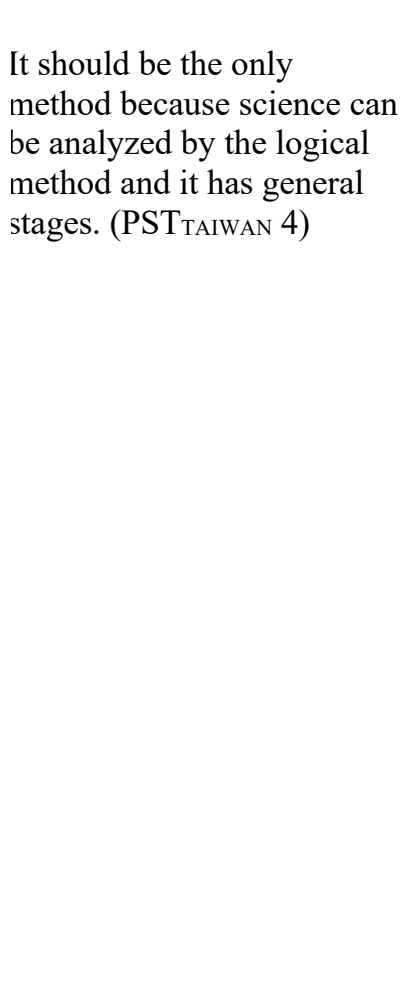 \\
\hline
\end{tabular}

*PST- Preservice Science Teacher

The $\mathrm{b}$ and $\mathrm{c}$ of the first question in the second dimension of the VASI scale and the preservice science teachers' views about the method and steps of scientific inquiry were tried to be determined. One of the most common beliefs about science is the idea that there is only one standard method in scientific research. When the findings regarding this dimension were examined, most of the preservice science teacher in Taiwan $(66.2 \%)$ had a scientific view and 
were able to justify their answers with various examples. But, unfortunately, more than half of the science teachers in Turkey (59.1\%) is determined to have a "naive" view towards this aspect. These preservice science teachers emphasized that scientists should follow a single way to reach scientific information, otherwise their studies will not have a scientific quality. Based on the findings of this study, it is possible to say that the preservice science teachers in Turkey have an important misconception about this aspect.

\section{Aspect: Inquiry procedures are guided by the question asked}

In Turkey and in Taiwan, some examples of preservice science teachers' responses to the third aspect of scientific inquiry are presented in Table 3.

Table 3.

Examples of Preservice Science Teachers' Responses Representing their Informed, Mixed and Naive Views on the Third Aspect of Scientific Inquiry

\begin{tabular}{|c|c|c|c|}
\hline $\begin{array}{l}\text { 3. Aspect of Scientific } \\
\text { Inquiry }\end{array}$ & Informed & Mixed & Naive \\
\hline \multirow[t]{2}{*}{$\begin{array}{l}\text { Inquiry procedures are } \\
\text { guided by the question } \\
\text { asked }\end{array}$} & $\begin{array}{l}\text { Team A is better, because it } \\
\text { is necessary to keep } \\
\text { something under control. } \\
\text { The effect of other factors } \\
\text { on what we keep constant is } \\
\text { being investigated. There } \\
\text { may also be two tires or } \\
\text { more. So team A is more } \\
\text { accurate because it tries } \\
\text { multiple brand tires. } \\
\text { (PST TURKEY 4) }\end{array}$ & $\begin{array}{l}\text { Those who try a brand in } \\
\text { different ways have done } \\
\text { the proper experiment, } \\
\text { tried three tires, but I'm } \\
\text { not sure... I think this is } \\
\text { more accurate because the } \\
\text { other group is a controlled } \\
\text { experiment that has tried } \\
\text { different brands. } \\
\left(\text { PST }_{\text {TURKEY } 5)}\right.\end{array}$ & $\begin{array}{l}\text { I think it would be better } \\
\text { to try a tire in three } \\
\text { different ways, because } \\
\text { we can understand why. } \\
\text { But if we try different } \\
\text { tires with different } \\
\text { processes, it would not } \\
\text { be more convincing. } \\
\text { (PST }\end{array}$ \\
\hline & $\begin{array}{l}\text { Team A is trying different } \\
\text { brand tires in different } \\
\text { ways. Team B is trying } \\
\text { only one brand on the road. } \\
\text { Since different brand tires } \\
\text { are asked in the question, } \\
\text { team B cannot answer the } \\
\text { question of which brand } \\
\text { tires are better. But team A } \\
\text { can answer. (PSTTAIWAN } 66 \text { ) }\end{array}$ & $\begin{array}{l}\text { Since the brand is asked, } \\
\text { one time is not enough. } \\
\text { He needs to try more than } \\
\text { one. (PST TAIWAN } 11 \text { ) }\end{array}$ & $\begin{array}{l}\text { There is only one } \\
\text { control variable. Thus, } \\
\text { the link between the } \\
\text { brand of the wheel and } \\
\text { its easy explosion can be } \\
\text { found. (PSTTAIWAN 10) }\end{array}$ \\
\hline
\end{tabular}

*PST- Preservice Science Teacher

Data for the this aspect of scientific inquiry, which is "The research process is guided by the questions", collected by the fifth question of VASI and the findings of the study stated that majority of the preservice science teachers in both countries Turkey $(65.9 \%)$ and Taiwan (70\%) have "informed" view. Based on this result, it can be said that science teacher candidates are 
aware that the scientific research process varies depending on the research question. In the "informed" view responses to this question, expressions such as "different brands of tires should be tried in the experimental design because the possibility of explosion of different brand tires is asked" is frequently encountered.

\section{Aspect: All scientists performing the same procedures may not get the same results.}

In Turkey and in Taiwan, some examples of preservice science teachers' responses to the fourth aspect of scientific inquiry are presented in Table 4.

Table 4.

Examples of Preservice Science Teachers' Responses Representing their Informed, Mixed and Naive Views on the Fourth Aspect of Scientific Inquiry

\begin{tabular}{|c|c|c|c|}
\hline $\begin{array}{l}\text { 4.Aspect of Scientific } \\
\text { Inquiry }\end{array}$ & Informed & Mixed & Naive \\
\hline \multirow[t]{2}{*}{$\begin{array}{l}\text { All scientists } \\
\text { performing the same } \\
\text { procedures may not get } \\
\text { the same results. }\end{array}$} & $\begin{array}{l}\text { I think there will be a } \\
\text { difference. Because we are } \\
\text { all different, we think } \\
\text { differently. Even if we } \\
\text { look at the same thing, we } \\
\text { will find different things. } \\
\text { (PST }_{\text {TURKEY } 3 \text { ) }}\end{array}$ & $\begin{array}{l}\text { The same question, } \\
\text { the same way. they } \\
\text { may have different } \\
\text { results or they may } \\
\text { have the same result! } \\
\text {..... But it is better that } \\
\text { they achieve the same } \\
\text { result, their } \\
\text { scientificity increases. } \\
\text { (PST TURKEY 15) }\end{array}$ & $\begin{array}{l}\text { They all come to the same } \\
\text { conclusion. Because } \\
\text { asking the same questions } \\
\text { and doing the same } \\
\text { process means doing the } \\
\text { same scientific research. If } \\
\text { we consider the situation } \\
\text { of getting different results, } \\
\text { maybe there will be error } \\
\text { situations. I think they } \\
\text { come to the same } \\
\text { conclusions of all kinds. } \\
\text { (PST TURKEY 2) }\end{array}$ \\
\hline & $\begin{array}{l}\text { They may not reach the } \\
\text { same conclusion. Everyone } \\
\text { thinks differently. Even if } \\
\text { we look at the same thing, } \\
\text { we create different } \\
\text { thoughts, findings, } \\
\text { explanations. Even with } \\
\text { the same data, different } \\
\text { researchers can draw } \\
\text { different conclusions. } \\
\text { Different interests and } \\
\text { different infrastructures } \\
\text { also affect this. (PST TAIWAN } \\
\text { 29) }\end{array}$ & $\begin{array}{l}\text { They come to different } \\
\text { conclusions because } \\
\text { there are many } \\
\text { different factors in the } \\
\text { process. Researchers' } \\
\text { thoughts are } \\
\text { important. But it must } \\
\text { be repeatable for its } \\
\text { science. That is one. } \\
\left(\text { PST }_{\text {TAIWAN } 38)}\right.\end{array}$ & $\begin{array}{l}\text { Science is universal, } \\
\text { whoever does it, they } \\
\text { reach the same method, } \\
\text { the same question, the } \\
\text { same result. (PST TAIWAN } \\
\text { 34) }\end{array}$ \\
\hline
\end{tabular}

\footnotetext{
*PST- Preservice Science Teacher
}

The findings of this aspect of scientific inquiry; that the scientific data alone does not mean anything, the importance of reaching the result by the interpretation of the scientific data by the scientist; stated that more than half of the preservice science teachers in both countries, Turkey 
(52.2\%) and Taiwan (56.8\%), has been determined to have "informed" views. Besides, 37.5\% of preservice science teachers in Turkey and $41.3 \%$ of preservice science teachers in Taiwan for this aspect of scientific inquiry, as quite a high percentage, have "naive" view. Generally, in the statements of prospective teachers with insufficient opinions, it is determined that science is universal and scientists will reach the same result even if they use different methods.

\section{Aspect: Inquiry procedures can influence the results}

In Turkey and in Taiwan, some examples of preservice science teachers' responses to the fifth aspect of scientific inquiry are presented in Table 5.

Table 5.

Examples of Preservice Science Teachers' Responses Representing their Informed, Mixed and Naive Views on the Fifth Aspect of Scientific Inquiry

\begin{tabular}{|c|c|c|c|}
\hline $\begin{array}{l}\text { 5. Aspect of Scientific } \\
\text { Inquiry }\end{array}$ & Informed & Mixed & Naive \\
\hline \multirow[t]{2}{*}{$\begin{array}{l}\text { Inquiry procedures } \\
\text { can influence the } \\
\text { results }\end{array}$} & $\begin{array}{l}\text { They can come to the same } \\
\text { conclusion, or to different } \\
\text { conclusions. Here, the } \\
\text { individual differences of } \\
\text { scientists are important. } \\
\text { For example, two different } \\
\text { scientists who deal with a } \\
\text { question with different } \\
\text { methods can draw the same } \\
\text { conclusion because of } \\
\text { differences of thought, or } \\
\text { they can reach different } \\
\text { conclusions too. } \\
\text { (PST TURKEY 40) }\end{array}$ & $\begin{array}{l}\text { If they ask the same } \\
\text { questions and follow the } \\
\text { same procedures, they will } \\
\text { definitely come to the same } \\
\text { conclusion. If they asks the } \\
\text { same questions and follows } \\
\text { different processes, they } \\
\text { may reach the same } \\
\text { conclusion, or may not } \\
\text { reach the same conclusion } \\
\text { too. There may be } \\
\text { differences. (PST TURKEY } \\
\text { 26) }\end{array}$ & $\begin{array}{l}\text { Scientists ask the same } \\
\text { questions. Regardless of } \\
\text { the way, the same result } \\
\text { is obtained. (PST TURKEY } \\
61 \text { ) }\end{array}$ \\
\hline & $\begin{array}{l}\ldots \text { if the same data cannot } \\
\text { reach the same result even } \\
\text { if it is the same method, } \\
\text { they can reach different } \\
\text { results with more } \\
\text { possibilities here. Because } \\
\text { the processes followed are } \\
\text { different. (PSTTAIWAN 29) }\end{array}$ & $\begin{array}{l}\text {.....for example, the same } \\
\text { substance may come out of } \\
\text { different chemical } \\
\text { reactions, even if it is the } \\
\text { same chemical reaction } \\
\text { (for reasons such as } \\
\text { degrees, pressure), } \\
\text { different substances can } \\
\text { come out. We cannot know } \\
\text { this. (PST TAIWAN51) }\end{array}$ & $\begin{array}{l}\text {... minor errors in the } \\
\text { accuracy of the } \\
\text { processes applied and } \\
\text { the process they follow } \\
\text { may affect the result. } \\
(\text { PST TAIWAN } 60)^{\text {The }}\end{array}$ \\
\hline
\end{tabular}

\footnotetext{
*PST- Preservice Science Teacher
}

According to findings for this aspect that the research process can affect result, many preservice science teachers in both countries in Turkey (54.5\%) and in Taiwan (62.5\%) have "informed" view. Based on this result, it is possible to say that preservice science teachers who have 
"informed" view are aware that scientists who ask the same questions and follow different procedures can reach the same result or different result depending on the procedures performed. But the research findings shows that $31.8 \%$ of preservice science teachers in Turkey and $23.7 \%$ of preservice science teachers in Taiwan have "naive" view for this aspect of scientific inquiry. To this result, it is possible to say that these preservice science teachers have a lack of knowledge that the results of the research may differ depending on the difference of the research process.

\section{Aspect: Research conclusions must be consistent with the data collected}

In Turkey and in Taiwan, some examples of preservice science teachers' responses to the sixth aspect of scientific inquiry are presented in Table 6.

Table 6.

Examples of Preservice Science Teachers' Responses Representing their Informed, Mixed and Naive Views on the Sixth Aspect of Scientific Inquiry

\begin{tabular}{|c|c|c|c|}
\hline $\begin{array}{l}\text { 6.Aspect of } \\
\text { Scientific Inquiry }\end{array}$ & Informed & Mixed & Naive \\
\hline \multirow[t]{2}{*}{$\begin{array}{l}\text { Research conclusions } \\
\text { must be consistent } \\
\text { with the data collected }\end{array}$} & $\begin{array}{l}\text { With growth, the light is } \\
\text { inversely proportional. The } \\
\text { table says this. This plant } \\
\text { may not be a light-loving } \\
\text { plant. (PST TURKEY } 30 \text { ) }\end{array}$ & $\begin{array}{l}\text { B is more accurate. } \\
\text { When there is light, } \\
\text { plants grow. There must } \\
\text { be an inverse proportion. } \\
\text { (PST TURKEY 17) }\end{array}$ & $\begin{array}{l}\text { A is true. Light and plant } \\
\text { growth are directly } \\
\text { proportional because } \\
\text { plants do photosynthesis, } \\
\text { that is, they need light. } \\
\left(\text { PST }_{\text {TURKEY } 87)}\right.\end{array}$ \\
\hline & $\begin{array}{l}\text { B choice is correct. I made } \\
\text { a direct inference. The } \\
\text { numbers in the table are } \\
\text { inversely proportional to } \\
\text { each other. Although there } \\
\text { may be another factor, we } \\
\text { only have this data at the } \\
\text { moment. (PST TAIWAN } 63 \text { ) }\end{array}$ & $\begin{array}{l}\text { A and } \mathrm{C} \text { cannot be. No } \\
\text { inverse proportion. But } \\
\left.\text { wrong. (PST } \text { TAIWAN }_{76}\right)\end{array}$ & $\begin{array}{l}\text { In this experiment, no } \\
\text { other effective factor was } \\
\text { designed for plant } \\
\text { growth. Therefore, it can } \\
\text { be determined that such a } \\
\text { result has occurred due to } \\
\text { the reaction of the plant } \\
\text { only against sunlight. } \\
\text { (PST }\end{array}$ \\
\hline
\end{tabular}

*PST- Preservice Science Teacher

When examined the findings of this aspect that each research result should be supported by evidence from the data collected, the majority of preservice science teachers in both countries, in Turkey (79.5\%) and in Taiwan(72.5\%), have "informed" view. Based on this result, it can be said that most of the science teacher candidates who have scientific views towards this dimension are successful in reading data and have the knowledge that the results of the research depend on the data collected. In addition, $15.9 \%$ of preservice science teachers in Turkey and $18.7 \%$ of preservice science teachers in Taiwan were found to be missing in reading data; and it was determined that there was a lack of knowledge of these preservice science teachers that 
the results of any research depend on the data collected. These preservice science teachers ignored the data given in the question and selected the "plants grow longer in much light" option based on their knowledge.

\section{Aspect: Scientific data are not the same as scientific evidence}

In Turkey and in Taiwan, some examples of preservice science teachers' responses to the seventh aspect of scientific inquiry are presented in Table 7.

Table 7.

Examples of Preservice Science Teachers' Responses Representing their Informed, Mixed and Naive Views on the Seventh Aspect of Scientific Inquiry

\begin{tabular}{|c|c|c|c|}
\hline $\begin{array}{l}\text { 7.Aspect of Scientific } \\
\text { Inquiry }\end{array}$ & Informed & Mixed & Naive \\
\hline \multirow[t]{2}{*}{$\begin{array}{l}\text { Scientific data are not } \\
\text { the same as scientific } \\
\text { evidence }\end{array}$} & $\begin{array}{l}\text { Data is the information } \\
\text { collected, and evidence is } \\
\text { the implications presented } \\
\text { depending on this situation. } \\
\text { (PST TURKEY 30) }\end{array}$ & $\begin{array}{l}\text { Data and evidence are not } \\
\text { the same. Data are the } \\
\text { values we obtain, and } \\
\text { evidence is the result of } \\
\text { the data. (PST TURKEY } 6 \text { ) }\end{array}$ & $\begin{array}{l}\text { Data and evidence are } \\
\text { the same. Data is the } \\
\text { result of an experiment, } \\
\text { and evidence is to prove } \\
\text { that experiment. } \\
\text { (PSTTURKEY 13) }\end{array}$ \\
\hline & $\begin{array}{l}\text { Data is the information } \\
\text { collected, it is meaningless } \\
\text { by itself. If the data fits the } \\
\text { question after collection and } \\
\text { analysis, it is used as } \\
\text { evidence and makes sense. } \\
\text { (PST }_{\text {TAIWAN } 27)}\end{array}$ & $\begin{array}{l}\text { It is not exactly the same. } \\
\text { There is a difference } \\
\text { between data and } \\
\text { evidence. One of them } \\
\text { just has the result. The } \\
\text { other is evidence that can } \\
\text { support the hypothesis } \\
\text { after it is organized and } \\
\text { classified. The data } \\
\text { (numbers) do not } \\
\text { represent evidence, but } \\
\text { the evidence comes from } \\
\text { the data (number). } \\
\text { (PST TAIWAN 10) }\end{array}$ & $\begin{array}{l}\text { The data is also included } \\
\text { in the evidence. The data } \\
\text { may be correct; it may } \\
\text { also be wrong. But the } \\
\text { evidence has already } \\
\text { been proven in general. } \\
\text { (PSTTAIWAN } 8 \text { ) }\end{array}$ \\
\hline
\end{tabular}

*PST- Preservice Science Teacher

The findings for this aspect of scientific inquiry that the data and evidence serve different purposes in the scientific research showed that the $39.7 \%$ of preservice science teachers in Turkey examining and $26.2 \%$ of preservice science teachers in Taiwan have "informed" view. These preservice science teachers could identified the difference between data and evidence, and they stated that "The data is research-related information collected in the research. The proof is the researcher's explanation by supporting this data with various sources". On the other 
hand, findings of the research showed that nearly half of the preservice science teachers in Turkey (42\%) and over half of preservice science teachers in Taiwan (58.7\%) had "naive" view for this aspect. Because of this result it is possible to say that these preservice science techers could not differentiate the evidence and the data.

\section{Aspect: Explanations are developed from a combination of collected data and what is already known}

In Turkey and in Taiwan, some examples of preservice science teachers' responses to the eighth aspect of scientific inquiry are presented in Table 8 .

Table 8.

Examples of Preservice Science Teachers' Responses Representing their Informed, Mixed and Naive Views on the Eighth Aspect of Scientific Inquiry

\begin{tabular}{|c|c|c|c|}
\hline $\begin{array}{l}\text { 8.Aspect of } \\
\text { Scientific Inquiry }\end{array}$ & Informed & Mixed & Naive \\
\hline \multirow[t]{2}{*}{$\begin{array}{l}\text { Explanations are } \\
\text { developed from a } \\
\text { combination of } \\
\text { collected data and } \\
\text { what is already known }\end{array}$} & $\begin{array}{l}\text { I think they may have set } \\
\text { off from their anatomy. } \\
\text { From the anatomy of } \\
\text { present-day creatures over } \\
\text { extinct creatures that lived } \\
\text { in past ages. The hind limb } \\
\text { bones are thicker. Since the } \\
\text { center of gravity is } \\
\text { probably on the back and } \\
\text { for walking ... They may } \\
\text { have thought that the } \\
\text { second is the best } \\
\text { possibility. Scientists use } \\
\text { the results of previous } \\
\text { studies when explaining } \\
\text { scientific results. They } \\
\text { need to base scientific } \\
\text { knowledge on the source to } \\
\text { explain its results. It is } \\
\text { necessary to explain with } \\
\text { evidence. They use this } \\
\text { kind of information by } \\
\text { publicizing the results of } \\
\text { the experiment. } \\
\text { (PST TuRKEY } 5 \text { ) }\end{array}$ & $\begin{array}{l}\text { Support is needed to stand } \\
\text { up. The hind legs in the } \\
\text { second picture are } \\
\text { smaller. They look at } \\
\text { creatures and compare. } \\
\text { They use information. } \\
\text { (PSTTURKEY 22) }\end{array}$ & $\begin{array}{l}\text { His hind legs should be } \\
\text { stronger because his } \\
\text { balance is on him. If he } \\
\text { is weak, he cannot } \\
\text { benefit from many } \\
\text { things. The second } \\
\text { reason is that we can } \\
\text { think in terms of } \\
\text { moving faster. It can } \\
\text { catch its prey better. As } \\
\text { I said, there may be a } \\
\text { nutritional structure, } \\
\text { movement. Where the } \\
\text { weight is more or less. } \\
\text { While scientists are } \\
\text { explaining their results, } \\
\text { they set out by } \\
\text { examining the } \\
\text { environment. } \\
\text { (PST TURKEY } 6 \text { ) }\end{array}$ \\
\hline & $\begin{array}{l}\text { Scientists thought that } \\
\text { dinosaurs were moving } \\
\text { with two legs. The second } \\
\text { reason would be difficult to } \\
\text { walk with small feet, so } \\
\text { there should be big feet on }\end{array}$ & $\begin{array}{l}\text { In order to be able to walk } \\
\text { physiologically, it must be } \\
\text { this way. They looked at } \\
\text { the previous fossils. They } \\
\text { ask other researchers. } \\
\text { (PST TAIWAN 9) }\end{array}$ & $\begin{array}{l}\text { So hard. Need more } \\
\text { information. For } \\
\text { example, physiology, } \\
\text { front legs, hind legs and } \\
\text { muscle. (PST } \text { TAIWAN 73) }\end{array}$ \\
\hline
\end{tabular}




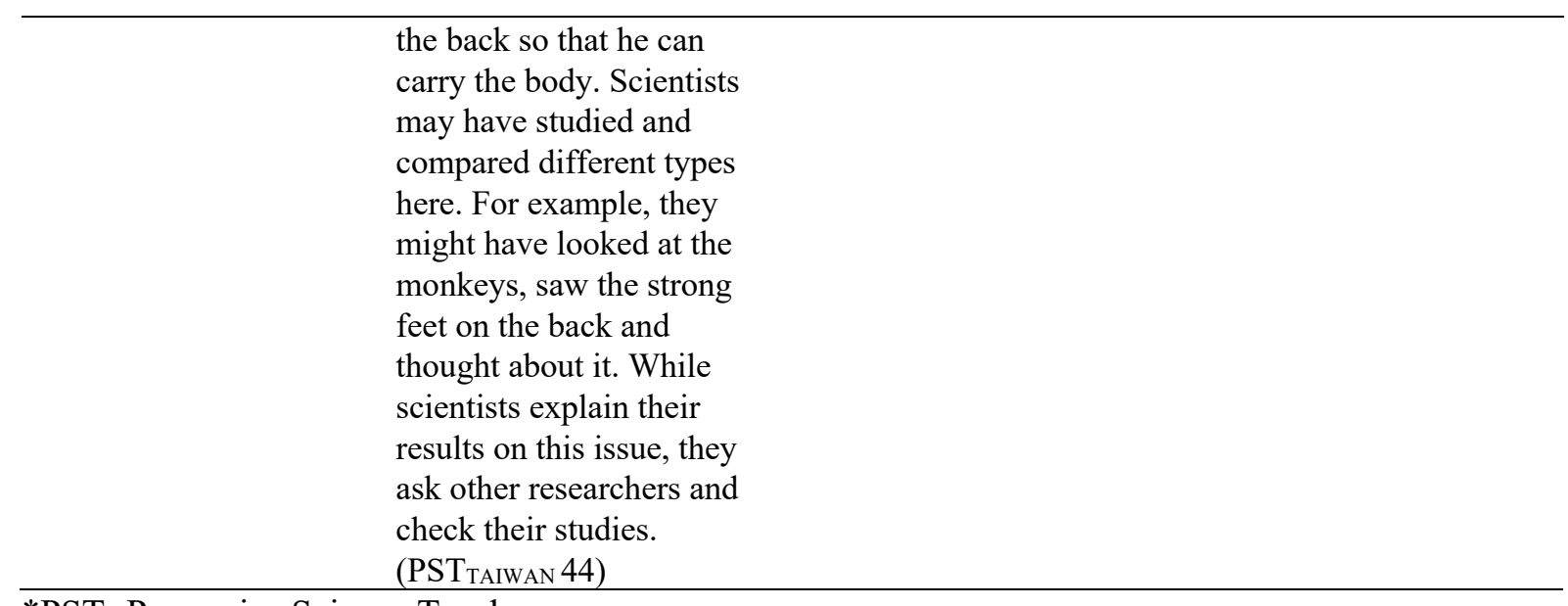

*PST- Preservice Science Teacher

According to findings for this aspect of scientific inquiry that the results of the researches are created by research data and interpretation of the available information, $40.9 \%$ of preservice science teachers in Turkey and $53.7 \%$ of preservice science teachers in Taiwan have "informed" view. It shows that preservice teachers who have this view are aware that the explanations made in scientific research are formed by comparing and combining the data collected in the study with the results of previous studies. But in addition, of the $30.7 \%$ of preservice science teachers in Turkey and $31.2 \%$ of preservice science teachers in Taiwan was determined to have "naive" view. The frequency values of preservice science teachers' answers regarding the aspect of VASI are presented in Table 9.

Table 9.

Frequency Values of Preservice Science Teachers' Views on the Dimensions of Scientific Research According to Country Variable

\begin{tabular}{llllllll}
\hline & & \multicolumn{3}{l}{ Informed } & \multicolumn{3}{l}{ Mixed } \\
\cline { 2 - 7 } & & $\begin{array}{l}\text { PST } \\
\text { inTurkey }\end{array}$ & $\begin{array}{l}\text { PST in } \\
\text { Taiwan }\end{array}$ & $\begin{array}{l}\text { PST } \\
\text { inTurkey }\end{array}$ & $\begin{array}{l}\text { PST in } \\
\text { Taiwan }\end{array}$ & $\begin{array}{l}\text { PST } \\
\text { inTurkey }\end{array}$ & $\begin{array}{l}\text { PST in } \\
\text { Taiwan }\end{array}$ \\
\hline Research Question & f & 25 & 32 & 3 & 8 & 60 & 40 \\
Scientific Method & $\mathrm{f}$ & 32 & 53 & 4 & 7 & 52 & 20 \\
Research Process & $\mathrm{f}$ & 61 & 56 & 3 & 4 & 24 & 20 \\
Social Effect on Science & $\mathrm{f}$ & 50 & 44 & 5 & 7 & 33 & 29 \\
$\begin{array}{l}\text { Process-Result Relationship } \\
\text { in Research }\end{array}$ & $\mathrm{f}$ & 48 & 50 & 12 & 11 & 28 & 19 \\
Research Result & $\mathrm{f}$ & 70 & 58 & 4 & 7 & 14 & 15 \\
$\begin{array}{l}\text { Data-Evidence Difference } \\
\text { f }\end{array}$ & $\mathrm{f}$ & 37 & 21 & 16 & 12 & 35 & 47
\end{tabular}


*PST- Preservice Science Teacher

The findings of the research, more than half of preservice science teachers in Turkey at the four aspects of scientific inquiry, and more than half of preservice science teachers in Taiwan at the six aspects of scientific inquiry shows that they have "informed" view. In addition, findings showed that in five aspects of scientific inquiry, preservice science teachers in Taiwan have more "informed" view than preservice science teachers in Turkey. The chi-square test was conducted to compare the views of preservice science teachers in the two countries regarding the aspect of scientific inquiry and the results are presented in Table 10.

Table 10.

Chi-Square Test Results of Preservice Science Teachers for VASI

\begin{tabular}{lll}
\hline Aspects of Scientific Inquiry & $\chi^{2}$ & $p$ \\
\hline Research Question & 6.76 & $0.03^{*}$ \\
Scientific Method & 19.89 & $0.00^{*}$ \\
Research Process & 3.26 & 0.19 \\
Social Effect on Science & 1.12 & 0.56 \\
Process-Result Relationship in Research & 1.43 & 0.48 \\
Research Result & 1.60 & 0.44 \\
Data-Evidence Difference & 4.89 & 0.08 \\
Scientific Explanation & 4.89 & 0.08 \\
\hline \multirow{2}{*}{$*(\chi 2, \mathrm{p}<0.05)$} & &
\end{tabular}

When Table 10 is examined, it has been shown that there is a significant difference in the answers given by preservice science teachers to the first and second dimensions of scientific inquiry, according to the country variable. These differences for both of aspects of scientific inquiry is positive in terms of preservice science teachers in Taiwan $\left[\chi^{2}(1)=6.76, p=0.03 ; \chi^{2}\right.$ $(1)=19.89, p=0.00]$. It was determined that there was no significant difference in the answers given by the preservice science teachers for the other six aspects of scientific inquiry, according to the country variable. 


\section{Discussion and Conclusion}

This study has been planned to analyze views of preservice science teachers on scientific inquiry in Turkey and Taiwan and to make comparisons for finding out the differences. According to the conclusions of the analysis, it is found that there are some differences between the views of preservice science teachers on scientific inquiry in both countries. The conclusions of the study can be summarized as following:

One of the most significant conclusions of this study is that most preservice science teachers in Turkey and Taiwan have "inadequate" views about scientific inquiries always starting with a problem and not necessarily having to test a hypothesis. The research findings obtained from both countries indicate that most of the preservice science teachers state that scientific inquiries can start out of curiosity or by chance and do not always need to start with a problem. In addition, it is found that many of the preservice science teachers cannot distinguish scientific questions from daily ones. Therefore, as the answers of the preservice science teachers in both countries are not satisfying, science teacher education programs in both countries can be considered to have deficiencies. Similar results have also been obtained from the researches about teachers and preservice science teachers conducted by Karaman and Apaydin (2014), Şenler (2015), Bologna Soares de Andrade and Cola Levoratob (2017), Leblebicioğlu et al. (2017), Aydemir, Uğraş, Cambay and Kılıç (2017). These studies show that teachers and preservice science teachers have inadequate information about that scientific inquiries have to start with scientific questions. As the questions of scientific inquiries determine purpose of the research, data collection method, analysis and evaluation methods (Lewis, 2014; NRC, 2000), the conclusion actually indicates that preservice science teachers know scientific research only as a concept, but do not deeply comprehend the meaning.

There is not only one scientific method and science does not fully depend on experiments. McComas (2000) states that doing experiment is the most useful method in science but it is not the only one. Therefore, it will be incorrect and misleading to call physical science as "experimental science". Physical sciences contribute hugely to science by means of theoretical thinking methods and theoretical structures. The conclusion of the study indicates that although preservice science teachers in Taiwan has a better level of knowledge about probability of various methods in scientific inquiry, preservice science teachers in Turkey have a lack of knowledge on this issue. Furthermore, many preservice science teachers participated in the 
study in Turkey cannot discriminate between experiment and observation. The preservice science teachers have been noticed to usually consider that science will not be possible without experiment and experiment must certainly be conducted to prove accuracy of information. It has also been determined that these preservice science teachers have a false opinion about observation is not being adequately scientific. One of the reasons of this false opinion is that experimental approach is often explained as "scientific method" in textbooks and implementation classes as stated by Schwartz, Lederman and Lederman (2008) and thus, students have adopted the concept of "experiment" as scientific method. Similar conclusions have also been emphasized in other studies. (Palmquist \& Finley, 1997; Doğan, 2010; Abd-ElKhalick \& BouJaude, 1997; Dickinson, Abd-El-Khalick \& Lederman, 2000; Abd-el-Khalick \& Akerson, 2004; Aslan, Yalçın \& Taşar, 2009; Arı, 2010; Doğan, 2010; Karaman \& Apaydın, 2014; Dursun, 2015; Öztürk, 2015; Bayır 2015; Ogochukwu, 2016; Yenice \& Atmaca 2017; Adisendjaja, Rustaman, Redjeki \& Satori 2017). Another reason is that experimental researches are given as examples of scientific inquiry and taught in lessons and experimental studies are mostly conducted while the students learn steps of a scientific inquiry. In implementation classes, preservice science teachers have opportunity to experience practically that scientific observations are conducted in a way that an observer watches natural phenomena carefully without any intervention, which leads the phenomena to be comprehended as scientifically reliable. The other conclusion of the study is that research process is conducted with questions.

The research question asked in a scientific inquiry is the most important element for defining the methods and techniques to be applied. The way of asking questions may even cause to change the research method. In this respect, teachers and students should be aware of the importance of relation between question and research. In analysis of this study, it is inferred that a great majority of preservice science teachers both in Turkey $(65.9 \%)$ and Taiwan $(70 \%)$ has a "scientific" view about research question is directing research process. As based on this inference, we can conclude that most of preservice science teachers in both countries are aware of the fact that scientific inquiry process can change according to the research question. As emphasized in studies of Karışan, Şenler and Bilican (2017) who have received similar findings, lessons given to preservice science teachers are effective in helping them have a scientific view of the fact that scientific inquiry is guided by questions.

As scientists work in a social, cultural, historical and political environment, science is a social activity and is influenced by values. Personal attitudes, values, opinions, thoughts, judgement, 
creativity and imagination of the scientists play a quite important role in their doing science. More than half of the preservice science teachers in Turkey (56.8\%) and Taiwan (55\%) have "informed" view about that the scientists who follow the same method in a scientific inquiry can reach different results. As similar to the conclusions of this study, Liang, Chen, Chen and Kaya conducted a study with Turkish, Chinese and American preservice teachers in 2006 and found that although these preservice teachers are from different countries, they have the scientific view of the fact that the scientists may reach different results even if they use the same methods. On the other hand, it is indicated in analysis of results of many researches (Çelikdemir, 2006; Arı, 2010; Bayır, 2016) that teachers and preservice teachers are not knowledgeable enough about explaining social and cultural factors in formation of scientific inquiry. For instance, unlike the findings of this study, Aydemir, Uğraş, Cambay and Kılıç (2017) have observed that preservice teachers have a false notion about that scientists who research the same questions must not reach different conclusions for reliability of the research. In the research conducted by Çavuş (2010), he has also found that preservice teachers think science is objective and scientists reach scientific information in the light of data and perceptible information and without including their subjective opinion.

In scientific inquiry, data is not the only distinctive factor of the research question. Interpretation of data and reaching different results indicate creative aspect of science (Osborne, Collins, Ratcliffe, Millar and Duschl, 2003). The scientists, who ask similar questions, follow similar methods and even use the same data, can reach different but acceptable results because the scientists can comprehend the same data diversely and focus mainly on one part of the data (Schwart, Lederman \& Lederman, 2008). The preservice teachers, who state that scientists work in a social community and are aware of this feature, are able to educate students who are openminded about different ideas and can make original researches. According to conclusions of the research in this respect, more than half of preservice science teachers in Turkey (54.5\%) and Taiwan (62.5\%) have "informed" view. However, it is seen that more preservice science teachers have "informed" level-view in Taiwan when compared to the numbers in Turkey. The reason for the difference can be that implementation classes in the curriculum of science teacher education are more than the ones in Turkey within the context of number and duration.

The conclusion of the research based on that scientific inquiry results must be consistent with the collected data and be supported by evidences obtained by the collected data indicates that the majority of preservice science teachers in Turkey (79.5\%) and Taiwan $(72.5 \%)$ have 
"informed" view. This conclusion of the research has similarity with the study conducted by Karışan, Bilican and Şenler (2017). It may have helped the preservice science teachers contribute to having informed level view as they have opportunity especially to compare the results of their own studies, which they have carried out during practices in laboratory classes, with the collected data and thanks to experiences they gain about science. However, $40.9 \%$ of preservice science teachers in Turkey and $53.7 \%$ of preservice science teachers in Taiwan have the informed view about the fact that the results of scientific inquiries are formed by interpretation of research data and current knowledge. In fact, the percentages in both countries are not very satisfying and it may be resulted from inefficient concentration of preservice science teachers on the process while they explain the results they obtain in laboratory practices, their inefficient questioning about cause and effect relation.

Another conclusion of the research indicates that most of preservice science teachers in Turkey (\%42) and Taiwan (58.7\%) cannot discriminate between data and evidence. In addition, a great majority of preservice science teachers (65\%-75\%) stated that data and evidence are different but it has been observed that they cannot define the concepts properly or have misconception. As based on the conclusion found in many researches ((Abd-El-Khalick; 2005; Tuncel, 2012; Karaman \& Apaydın, 2014; Öztürk, 2015; Aydemir, Uğraş, Cambay \& Kılıç, 2017), it is likely to underline that curriculums of science teacher education should mostly be based on case study or discussion and there should be more activities to identify the relation between data and evidence.

As all the conclusions are evaluated in general, it can be inferred that preservice science teachers in Taiwan have more informed view than those in Turkey among five of eight aspects of the scientific research. These preservice science teachers are more willing to use information, which they get in the lessons on scientific inquiry, and to take education approach they have adopted (Haefner \& Zembal-Saul 2004, Kim \& Chin 2011), which results from the difference between curriculums of science teacher education in Turkey and Taiwan and the classes in both program do not have the same effects.

It is obvious if teachers do not know about the concepts and views, they will not be able to convey them to their students. That preservice teachers have an adequate view on scientific inquiry plays a major role in development of professional experience in future (Gess-Newsome, 2002; Lederman, 1998, 2007). The conclusions of the research indicate that faculties of 
education are incapable of having preservice teachers to adopt these views on scientific inquiry and cannot meet preservice science teachers' needs in this field. Therefore, it is a need to restructure teacher education system and to form a new theoretical frame in training of teachers for science education. Nevertheless, preservice science teachers' opinions on scientific inquiry should initially be identified for this new restructure and the foundation needs to be laid by considering these conclusions.

\section{Acknowledgements}

We wish to thank Pamukkale University- Scientific Research Center for their financial support towards the completion of this project. We also thank Prof. Dr. Liu SY for her support in this study. 


\section{References}

Abd-El-Khalick, F., \& Lederman, N. G. (2000). The influence of history of Science courses on students' views of nature of science. Journal of Research in Science Teaching, 37(10), 1057-1095. Retrieved from http://citeseerx.ist.psu.edu/viewdoc/download?doi=10.1.1.466.265\&rep=rep1\&type=pdf Abd-El-Khalick, F. (2005). Developing deeper understandings of nature of science: The impact of a philosophy of science course on preservice science teachers' views and instructional planning. International Journal of Science Education, 27(1), 15-42. https://doi.org/10.1080/09500690410001673810

Abd-El-Khalick, F., \& Akerson, V. L. (2004). Learning about nature of science as conceptual change: Factors that mediate the development of preservice elementary teachers' views of nature of science. Science Education, 88(5), 785-810. https://doi.org/10.1002/sce.10143|

Adisendjaja, Y.H., Rustaman, N.Y., Redjeki, S., \& Satori, D. (2017). Science teachers' understanding of scientific inquiry in teacher professional development. Journal of Physics: Conference Series, 812, 1-5. https://doi.org/10.1088/1742-6596/812/1/012054

American Association for the Advancement of Science (AAAS) (1993). Project 2061: Benchmarks for Science Literacy. New York, NY: Oxford University Press. Retrieved from http://www.project2061.org/publications/bsl/online/index.php

Anderson, R. D. ( 2002). Reforming science teaching: What research says about inquiry. Journal of Science Teacher Education, 13(1), 1-12. https://doi.org/10.1023/A:1015171124982

Ar1, Ü. (2010). Investigation of the preservice science teachers? and preservice classroom teachers? wiews on nature of science (Unpublished master's thesis). Frrat University, Elazı $\breve{g}$.

Aslan, O., Yalçın N., \& Taşar, M. F. (2009). The views of the teachers of the science and technology on the nature of science. Ahi Evran Üniversitesi Eğitim Fakültesi Dergisi. 10(3), 1-8. Retrieved from http://kefad.ahievran.edu.tr/InstitutionArchiveFiles/f44778c7- 
ad4a-e711-80ef-00224d68272d/d1a3a581-af4a-e711-80ef00224d68272d/Cilt10Sayi3/JKEF_10_3_2009_1_8.pdf

Aydemir, S., Ugras, M., Cambay, O., \& Kilic, A. (2017). prospective pre-school teachers' views on the nature of science and scientific inquiry. Üniversitepark Bülten, 6(2), 74-87. Retrieved from https://doi.org/10.22521/unibulletin.2017.62.6

Bayır, E. (2016). Science teachers' views about nature of science: an example of cognitive map. Kastamonu Eğitim Dergisi, 24(3), 1419-1436. Retrieved from https://dergipark.org.tr/tr/download/article-file/210050

Bologna Soares de Andrade, M., A., \& Cola Levoratob, A.,C. (2017) brazilian learners' understanding about scientific inquiry. Proceeding of X Congreso Internacional Sobre Investigación En Didáctica De Las Ciencias, 3555-3559. Retrieved from https://ddd.uab.cat/pub/edlc/edlc_a2017nEXTRA/56._brazilian_learners_understanding. pdf

Brown, A. S., \& Brown, L. L. (2007). What are Science and Math test scores really telling us? the bent of tau beta pi, 13-17. Retrieved from http://www.tbp.org/pages/Publications/Bent/Features/W07

Büyüköztürk, Ş., K1lıç Çakmak, E., Akgün, Ö.E., Karadeniz, Ş., \& Demirel, F. (2014). Bilimsel araştırma yöntemleri (17th ed.). Ankara: Pegem Yayınları.

Çavuş, S. (2010). Improving science and mathematics pre-service teachers' conseptions of nature of science (Unpublished master thesis). Abant İzzet Baysal Üniversitesi, Bolu.

Çelikdemir, M. (2006). Examining middle school students' understanding of the nature of science (Unpublished master thesis), Middle East Techical University, Graduate School pf Social Sciences, Ankara.

Dickinson, V. L., Abd-el Khalick, F., \& Lederman, N. G. (2000). Changing elementary teachers' views of the NOS: Effective strategies for science methods courses. $E D, 441$ 680.

Doğan, N. (2017). Blending problem based learning and history of science approaches to enhance views about scientific inquiry: New wine in an old bottle. Journal of Education and Training Studies, 5 (10), 99-112. https://doi.org/10.11114/jets.v5i10.2646

Driver, R., Leach, J., Millar, R., \& Scott, P. (1996). Young people's images of science. Philadelphia: Open University Press. 
Dursun, B. (2015). The study of the opinions of the teacher candidates of science as regards the nature of the science and technology (Unpublished master thesis), İnönü University, Graduate School Of Educational Sciences, Malatya.

Gess-Newsome, J. (2002). The use and impact of explicit instruction about the nature of science and science inquiry in an elementary science methods course. Science and Education, 11, $55-67$.

Retrieved from https://link.springer.com/content/pdf/10.1023/A:1013054823482.pdf

Haefner, L. A., \& Zembal-Saul, C. (2004). Learning by doing? Prospective elementary teachers' developing understandings of scientific inquiry and science and learning. International Journal of Science Education, 26(13), 1653-1674. https://doi.org/10.1080/0950069042000230709

Higher Education Institute (HEI) (2007). Education faculty teacher training undergraduate programs. Retrieved from https://www.yok.gov.tr/documents/10279/30217/E\%C4\%9E\%C4 \%B0T\%C4\%B0M+FAK\%C3\%9CLTES\%C4\%B0\%20\%C3\%96\%C4\%9ER ETMEN+YET\%C4\%B0\%C5\%9ET\%C4\%B0RME+L\%C4\%B0SANS+PR OGRAMLARI.pdf/054dfc9e-a753-42e6-a8ad-674180d6e382>

Hill, H. C., Rowan, B., \& Ball, D. L. (2005). Effects of teachers' mathematical knowledge for teaching on student achievement. American Educational Research Journal, 42(2), 371406. http://dx.doi.org/10.3102/00028312042002371

Johnson, R. B., \& Onwuegbuzie, A. J. (2004). Mixed Methods Research: A Research Paradigm Whose Time Has Come. Educational Researcher, 33(7), 14-26. https://doi.org/10.3102/0013189X033007014

Leblebicioglu, G., Metin, D., Capkinoglu, E., Cetin, P. S., Eroglu Dogan, E., \& Schwartz, R. (2017). Determination of the change in the students' views of nature of scientific inquiry at a science camp. Science and Education, 26, 889-917. https://doi.org/10.1007/s11191017-9941-z

Lederman, J. S. (2009). Teaching scientific inquiry: Exploration, Directed, Guided, and Opened-Ended Levels. In National geographic science: Best practices and research base (pp. 8-20). Hapton-Brown Publishers. 
Lederman N.G., Lederman J.S., Bartos,S. A., Bartles, S.L., Meyer, A.A., \& Schwartz, R.S. (2014). Meaningful assessment of learners' understandings about scientific inquiry-the views about scientific inquiry (VASI) questionnaire. Journal of Research In Science Teaching, 51(1), 65-83. https://doi.org/10.1002/tea.21125|

Lederman, N., \& Lederman, J. (2012). Nature of scientific knowledge and scientific inquiry: Building instructional capacity through professional development. In B. J. Fraser, K. Tobin \& C. J. McRobbie (Eds.), Second International Handbook of Science Education (24th ed.), (pp. 335-359). Dordrecht: Springer

Lederman, N.G., Lederman, J.S., \& Antink, A. (2013). Nature of science and scientific inquiry as contexts for the learning of science and achievement of scientific literacy. International Journal of Education in Mathematics, Science and Technology, 1(3), 138-147. Retrieved from https://files.eric.ed.gov/fulltext/ED543992.pdf

Liang, L. L, Chen, S., Chen, X., Kaya, O. N., Adams, A. D., Macklin, M., \& Ebenezer, J. (2008). Assessing preservice elementary teachers' views on the nature of scientific knowledge: A dual-response instrument. Asia-Pacific Forum on Science Learning and Teaching, 9(1), 1-20. https://www.eduhk.hk/apfslt/download/v9_issue1_files/liang.pdf

Karaman, A., \& Apaydın, S. (2014). The Impact of an astronomy science summer camp on the nature of scientific inquiry understandings of elementary teachers. Kastamonu Ĕ̈itim Dergisi, 22(2), 841-864. Retrieved from https://dergipark.org.tr/tr/download/articlefile/209935

Karışan, D., Bilican, K., \& Şenler, B. (2017). The Adaptation of the views about scientific 1nquiry questionnaire: A validity and reliability study. Inönü Üniversitesi Ĕ̌itim Fakültesi Dergisi, 18(1), 326-343. https://doi.org/10.17679/inuefd.307053

Keser, Ö. F. (2005). Recommendations towards developing educational standards to improve science education in Turkey. The Turkish Online Journal of Educational Technology TOJET, 4(1), 46-53. Retrieved from http://www.tojet.net/articles/v4i1/416.pdf

Kilpatrick, A.J., Swaford, J., \& Findell, B. (2001). Adding it UP: Helping children learn mathematics. Washington, DC: Natonal Academy Press.

Kim M., \& Chin C. (2011), Pre-service teachers' views on practical work with inquiry orientation in textbookoriented science classrooms. International Journal of 
Environmental and Science Education, 6(1), 23-37. Retrieved from https://files.eric.ed.gov/fulltext/EJ930276.pdf

Ma, H. (2011). Internet of things: Objectives and scientific challenges. Journal of Computer Science and Technology, 26(6), 919-924. https://doi.org/10.1007/s11390-011-1189-5

MEB (2005). İlköğretim fen ve teknoloji dersi öğretim programı. Retrieved from https://ttkb.meb.gov.tr

MEB (2018). Illköğretim fen ve teknoloji dersi ögretim programi. Retrieved from http://mufredat.meb.gov.tr/ProgramDetay.aspx?PID=325

MEB (2016). National PISA Report. Retrieved from http://timss.meb.gov.tr/

Mccomas, W. F. (2000). The principal elements of the nature of science: dispelling the myths In W. F. McComas (Ed.), The Nature of Science in Science Education. Rationales and Strategies. Dordrecht, The Netherlands: Kluwer Academic.

Ministry of Education [MOE], Taiwan. (2001) White paper on higher education, Taipei: MOE.

Morrison, J. A., Raab, F. J., \& Ingram, D. (2009). Factors influencing elementary and secondary teachers' views of the nature of science. Journal of Research in Science Teaching, 46(4), 384-403. https://doi.org/10.1002/tea.20252|

National Research Council (NRC) (1996). National Science Education Standards. Washington, DC: The National Academies Press. https://doi.org/10.17226/4962

Osborne, J., Collins, S., Ratcliffe, M., Millar, R., \& Duschl, R. (2003). What "ideas-aboutscience" should be taught in school? A Delphi study of the expert community. Journal of Research in Science Teaching, 40, 692-720. https://doi.org/10.1002/tea.10105

Palmquist, B. C., \& Finley, F. N. (1997). Pre-service teachers' views of the nature of science during a postbaccalaureate science-teaching program. Journal of Research in Science Teaching, 34(6), $595-615$.

https://doi.org/10.1002/(SICI)1098-2736(199708)34:6<595::AID-TEA4>3.0.CO;2-I|

Reif, F., \& Larkin, J. H. (1991). Cognition in scientific and everyday domains: Comparison and learning implications. Journal of Research in. Science Teaching, 28, 733-760. https://doi.org/10.1002/tea.3660280904 
Schwartz, R.S., Lederman N.G., \& Lederman, J.S. (April, 2008). An instrument to assess views of scientific inquiry: the vosi questionnaire. Paper presented at the Annual Meeting of the National Association for Research in Science Teaching, Baltimore, MD. Retrieved from http://homepages.wmich.edu/ rschwart/docs/VOSInarst08.pdf. Accessed 13 January 2014.

Solomon, J., (1991). Teaching about the nature of science in the British National Curriculum. Science Education, 75 (1), 95-103. https://doi.org/10.1002/sce.3730750109|

Schneider, R., Krajcik, J., Marx, R.W., \& Soloway, E. (2002). Student learning in project-based science classrooms. Journal of Research in Science Teaching. 39(5), 410-422. https://doi.org/10.1002/tea.10029|

Schwartz, R.S., Lederman, N.G., \& Lederman, J.S. (April, 2008). An Instrument to Assess Views of Scientific Inquiry: The Vosi Questionnaire. Paper presented at the Annual Meeting of the National Association for Research in Science Teaching, Baltimore, MD. Retrieved from http://homepages.wmich.edu/ rschwart/docs/VOSInarst08.pdf. Accessed 13 January 2014.

Şenler, B. (2017). Examination of pre-service science teachers' science teaching self-efficacy beliefs and views about scientific inquiry. Eğitim Kuram ve Uygulama Araştırmaları Dergisi, 3(2), 50-59. Retrieved from http://ekuad.com/articles/fen-bilgisi-ogretmenadaylarinin-fen-ogretimine-yonelik-oz-yeterlik-inanclari-ile-bilimsel-sorgulama.pdf

Tuncel, G. (2012). Using of semantic feature analysis in the assessment process of social studies teacher candities. Marmara Coğrafya Dergisi, 25, 127-136. Retrieved from https://dergipark.org.tr/tr/download/article-file/3279

Wang, J., Lv, Y., Jou, M., \& Zhang, J. (2016). Research on the effects of cloud-based pedagogy for creative talents: A case study on chinese high school. Computers in Human Behavior, 63, 229-239. https://doi.org/10.1016/j.chb.2016.05.038

Yenice, N., \& Ceren-Atmaca, A. (2017). Fen Bilgisi öğretmen adaylarının bilimin ve bilimsel bilginin doğasına yönelik bilgi ve görüşlerinin belirlenmesi. Kuramsal Eğitim bilim Dergisi, 10(4), 366-393. http://dx.doi.org/10.5578/keg.27943. 